\title{
Studies on Value Added Kinnow - Aonla Blended Ready to Serve Beverage
}

\section{Vikram Balaji* and Prasad VM}

Department of Horticulture, SHIATS, Allahabad-211001, India

\begin{abstract}
Aonla and Kinnow fruits are considered to be the rich source of ascorbic acid, pectin, citric acid, and minerals like calcium and phosphorous. This study aimed at formulation of Kinnow and Aonla mix beverage just to take advantage of both fruits which are nutritionally diverse and have synergetic effect when consume simultaneously with peculiar taste, flavor and aroma. Three levels of each Cardamom and Ginger were used as herbal additives and were compared with control. All the herbal treatments were found better in respect of TSS, pH, Acidity and ascorbic acid content over Control. Highest mean TSS (15.13 $\left.{ }^{\circ} \mathrm{Brix}\right), \mathrm{pH}$ (3.50) and ascorbic acid content (19.4 Per cent) were observed in $\mathrm{T}_{5}$ (ginger powder @100 gram/ lit.), All the sensory parameters were based on the overall acceptability which was dependent on Colour, Texture , Flavour and Taste was recorded highest $\left(7.78\right.$ score) in $\mathrm{T}_{5}$ (ginger powder @100 gram/ lit.) Precisely, on the basis of results obtained it may be concluded that treatment $\mathrm{T}_{5}$ (ginger powder @100 gram/ lit.) can be used in commercialization of Kinnow-Aonla RTS. Thestudies on compositional changes in value-added Kinnow-Aonla RTS revealed that there was increase in the level of TSS and pH during the storage period (six months). The blended RTS were analyzed for its different physicochemical as well as sensory quality and sensory quality evaluated by adopting 9 point hedonic scale. The overall results showed that combination of different herbs gave better results for taste that of without herbal combinations. The developed RTS could be recommended for the large scale production at industrial level.
\end{abstract}

Keywords: Kinnow; Aonla; Herbs; RTS; Storage

\section{Introduction}

Fruits and Fruit Products both are an important supplement to the human diet as they provide almost all the vital components required for normal growth and development of the human body leading to the healthy physique and mind. Blending of fruit juices is practiced to overcome the high cost of some exotic fruit juices, scarcity or seasonal availability, balancing of strong flavors, high acidity, astringency, or bitterness, improving total soluble solids, bland flavor, improving and stabilizing color. Nutritional or phytochemical properties can be improved by blending which offers to adjust sugar/acid ratios and compensate undesirable juice consistency [1].The edible fruit tissues of Aonla (EmblicaofficinalisGeartn.) contains about 3 times as much protein and 160 times as much vitamin ' $\mathrm{C}$ ' as apple reported by [2]. The fruit contains a chemical substance called leucanthocyanin which retards the oxidation of Ascorbic acid. Antioxidant effect of Gallic acid, present in Aonla fruit is being well acknowledged. Dachiya [3] reported that the fresh fruit of Aonla are very rich source of Ascorbic acid $(454.40 \mathrm{mg} / 100 \mathrm{~g})$ and appreciable source of total sugar $(7.53 \mathrm{mg} / 100 \mathrm{~g})$, calcium (14.91 mg/100g), Iron $(0.62 \mathrm{mg} / 100 \mathrm{~g})$ and phosphorus $(11.81$ $\mathrm{mg} / 100 \mathrm{~g}$ ) and also has great potential for processing. Singh [4] noted that vitamin ' $C$ ' content is in no way lower than that of Barbados cherry. A number of the products like jam, squash, candy, dried shreds, powder, tablets, chutney, murabba and preserve may be prepared with ease from Aonla fruit.

Kinnow Mandarin (Citrus reticulata) is one of the most popular citrus fruit having attractive bright colour, appealing taste and flavor. Mandarinis the important Horticultural Crops, grown mainly of Assam, Karnataka, Madhya Pradesh, Maharashtra, Meghalaya, Mizoram, Nagaland, Rajasthan, Tamil Nadu and West Bengal and recently have had gain momentum to occupy subtropical part of Uttar Pradesh specially northern region. Farmers have gaining remunerative price growing this crop. There is a great potential to use this fruit in value added products such as juice, nectar, squash and RTS drinks. These types of citrus drinks are probably the most recognized and globally accepted fruit drinks $[5,6]$.
Young ginger rhizomes are juicy and fleshy with a very mild taste. They are often pickled in vinegar or sherry as a snack or just cooked as an ingredient in many dishes. They can also bestrewed in boiling water to make ginger tea, to which honey is often added. Mature ginger rhizomes are fibrous and nearly dry. The juice from old ginger roots is extremely potent and is often used as a spice in Indian recipes \& Chinese cuisine to flavor dishes. Ginger acts as a useful food preservative and has been proven to kill the harmful bacteria Salmonella[7]. Ginger powder is also used in certain food preparations particularly for the pregnant or nursing women [8].

Green cardamom in South Asia is broadly used to treat infections in teeth and gums, to prevent and treat throat troubles, congestion of the lungs and pulmonary tuberculosis, inflammation of eyelids and digestive disorders. It also used to break up kidney stones and gall stones, and was reportedly used as an antidote for both snake and scorpion venom. Cardamom is used as a spice and as an ingredient in traditional medicine in systems of the traditional Chinese medicine in China, Japan, Korea and used in Ayurveda in India [9]. Green cardamom powder is used as a spice for sweet dishes as well as traditional flavoring in coffee and tea[10].Beverages based on aonla and ginger continues to receive a considerable amount of attention reflecting a growing awareness of the potential of these products in the market place. These beverages have high nutritional quality and increased energy value. These could be particularly useful in

*Corresponding author: Vikram Balaji,Department of Horticulture, SHIATS Allahabad-211001, India, Tel: +91 532 2684281; Email: balaji.vikram55@gmail.com

Received August 14, 2013; Accepted December 31, 2013; Published January 08,2014

Citation: Balaji V, Prasad VM (2014) Studies on Value Added Kinnow Aonla Blended Ready to Serve Beverage. J Food Process Technol 5: 288 doi:10.4172/2157-7110.1000288

Copyright: ( 2014 Balaji V, et al. This is an open-access article distributed unde the terms of the Creative Commons Attribution License, which permits unrestricted use, distribution, and reproduction in any medium, provided the original author and source are credited. 
place where there is lack of food and improper nutrition leading to deficiencies of certain nutrients [11]. The development of any process for its economical utilization would be of great benefit to the beverage industry, the development of nutritionally value added product could therapeutically help on improving the health of consumers. Introduction of new types of value added beverages might improve socio-economic status of the country $[12,13]$.

\section{Materials and Methods}

Fully ripened, mature, fresh and sound Kinnow mandarin and Aonla fruit were takrn from the orchard of the Department of Horticulture, Sam Higginbottom Institute of Agriculture Technology \& Sciences (Deemed-to-be-University) Allahabad. Commercial grade white crystalline cane sugar, SB, big green cardamom and big size dried ginger were also taken from local market. Mature, uniform, diseased free Aonla fruits were selected. Fruits were then washed properly in tap water so that dirt that adhered on the fruits was properly cleaned. After pricking fruits were dipped in $2 \%$ salt solution for $24 \mathrm{hrs}$., then washedwith clean water and again dipped in $2 \%$ alum solution for 24 hrs., further washed with clean water and then blanched in boiling water for 10 mins. Then seeds were removed and segments were separated then passing through juicer to get juice. Kinnow Fruits were washed in tap water and then were peeled and divided into halves. Fruit juice is extracted in a citrus juice extractor. After juice extraction, Kinnow and Aonla raw juice was heated separately at $96^{\circ} \mathrm{C}$ for two minute to inactivate enzymes. Just then to make clean juice. It was filtered through 8 -folded cheese cloth to eliminate particulates and then cardamom and ginger extract were prepared with ratio 1:1 powder and water was heated at $96^{\circ} \mathrm{C}$ for 15 minute and also filtered through 8 -folded cheese cloth. All prepared juices, Na-Benzoate and sugar were blended in high speed blender along with other ingredients as shown in Table 1. Seven treatments combination were formulated with sugar and herbs (Cardamom and Ginger). The details of treatments are depicted in Table 2. The prepared beverage was kept in $250 \mathrm{ml}$ transparent glass bottles. After bottling, all juice samples were again heated at $96^{\circ} \mathrm{C}$ for $20 \mathrm{~min}$. Then samples were cooled with tap water and stored at $4^{\circ} \mathrm{C}$. Treated RTS samples are evaluated at 0,15 , and 30 days and so on up to 6 months storage for physiochemical analysis and sensory evaluation.

\section{Physiochemical analysis}

The total soluble solids in the samples were directly recorded by hand refractrometer and the results were expressed as per cent soluble solids ( $\left.{ }^{\circ} \mathrm{Brix}\right)$ and the values were corrected at $20^{\circ} \mathrm{C}$. Product $\mathrm{pH}$ was measured using an electronic $\mathrm{pH}$ meter. The $\mathrm{pH}$ meter was standardized by using buffers of $\mathrm{pH} 7.00$ and 4.00 prior to recording $\mathrm{pH}$ of the samples. The Ascorbic acid and Acidity was determined by using as describe by Larmond [14].

\section{Sensory evaluation}

Standard sensory evaluation procedures were followed to perform descriptive analysis; panelists were trained using repeated round table and individual evaluations of trial formulations of the control and value added samples. Hedonic scale method as described by Steel [15]

\begin{tabular}{|c|c|}
\hline Ingredients & Concentration (w/w) \\
\hline Juice & Aonla (10\%)+Kinnow(5\%) \\
\hline Water & $85 \%$ \\
\hline Na-Benzoate & $0.1 \%$ \\
\hline Sugar & $15 \%$ \\
\hline
\end{tabular}

Table 1: Formulation of Kinnow - Aonla RTS beverage.

\begin{tabular}{|c|c|c|}
\hline Treatment Symbols & Combinations of Herbs & Detail \\
\hline T0 & Plain Product & (without herbal powder) \\
\hline T1 & $0.5 \%$ & Cardamom powder \\
\hline T2 & $1.0 \%$ & Cardamom powder \\
\hline T3 & $1.5 \%$ & Cardamom powder $\mathrm{t}$ \\
\hline T4 & $0.5 \%$ & Ginger powder \\
\hline T5 & $1.0 \%$ & Ginger powder \\
\hline T6 & $1.5 \%$ & Ginger powder \\
\hline
\end{tabular}

Table 2: Combinations of Herbsused in Kinnow - Aonla RTS treatments.

was used for the organoleptic evaluation of RTS for color, flavor and taste by a panel of six judges at 0,15 and 30 days and so on up to 6 months storage period.

\section{Statistical analysis}

Statistical analyses of data were done by using ANOVA on all experimental groups with three replicates each. The experimental groups were then separated statistically by using Duncan's new multiple range tests, as described by [16].

\section{Results and Discussion}

\section{Total soluble solids (TSS) ${ }^{\circ}$ Brix}

The data on Total Soluble Solids (TSS) for all treatments has been presented in Table 3. TSS of Kinnow Aonla RTS was found to increase with increase in storage duration. After 6 months of storage, the level of TSS was reached up to $15.13^{\circ} \mathrm{Brix}$ which was being $15.01^{\circ} \mathrm{Brix}$ only in the initial stage. The effect of treatments on TSS changes was observed significantly. The lowest mean TSS $\left(15.10^{\circ} \mathrm{Brix}\right)$ was recorded in control while the highest TSS $\left(15.13^{\circ} \mathrm{Brix}\right)$ was observed in $\mathrm{T}_{6}$ (ginger powder $@ 150$ gram $/$ lit) and (15.13 ${ }^{\circ}$ Brix) in $\mathrm{T}_{5}$ (ginger powder @100 gram/ lit). All the ginger treatments levels were proved better in relation to TSS over cardamom respectively. Among the herbs Cardamom was found to inferior in improving the TSS level of the Kinnow Aonla RTS in all the treatments. Higher level of herbs yielded higher value of TSS. TSS was found gradually increased with increase in storage period. This might be due to the conversion of polysaccharides into sugars during hydrolysis process. Increase in TSS might also be attributed to the reduction in moisture content of the product with storage. Increase in TSS with storage was also by $[17,18]$ in their studies on lime juice; these results are also in connection with previous studies of [19] while studying on the canning and storage of oranges and in canned peaches.

\section{pH}

The $\mathrm{pH}$ has great importance to maintain shelf stability; $\mathrm{pH}$ can also influence the flavor and processing requirements of the Kinnow Aonla RTS. The data about $\mathrm{pH}$ (Table 3 ) indicated that there is a variation in control and value added treatments. Highest $\mathrm{pH}$ (3.51) was observed in $\mathrm{T}_{6}$ (ginger powder @150 gram) and (3.50) closely followed by $\mathrm{T}_{5}$ (ginger powder@100 gram/ lit). While the lowest pH (3.42) was experienced in $\mathrm{T}_{0}$ (Control). Storage intervals also influenced the $\mathrm{pH}$ of the Kinnow Aonla RTS. A decline in $\mathrm{pH}$ towards acidic region was noticed as the storage of beverage increased. Similar trend of decreasing $\mathrm{pH}$ was also reported by Nath [20].

\section{Acidity}

Acidity is also an important attribute because tartness is a major factor in the acceptability of Kinnow Aonla RTS drink. Acid gives the characteristic sourness to the product. Citric acid is the major acid in Kinnow and Aonla juice that enhance the characteristic flavor of Kinnow Aonla RTS. The data regarding acidity in different treatments of 
Citation: Balaji V, Prasad VM (2014) Studies on Value Added Kinnow - Aonla Blended Ready to Serve Beverage. J Food Process Technol 5: 288. doi:10.4172/2157-7110.1000288

Page 3 of 4

\begin{tabular}{|c|c|c|c|c|c|c|c|c|c|c|c|c|c|c|c|c|}
\hline \multirow{3}{*}{ Treatment } & \multicolumn{4}{|c|}{ TSS ( ${ }^{\circ}$ Brix) } & \multicolumn{4}{|c|}{$\mathrm{pH}$} & \multicolumn{4}{|c|}{ Acidity (\%) } & \multicolumn{4}{|c|}{ Ascorbic Acid (\%) } \\
\hline & \multicolumn{3}{|c|}{ Months after storage } & \multirow{2}{*}{ Mean } & \multicolumn{3}{|c|}{ Months after storage } & \multirow{2}{*}{ Mean } & \multicolumn{3}{|c|}{ Months after storage } & \multirow{2}{*}{ Mean } & \multicolumn{3}{|c|}{ Months after storage } & \multirow{2}{*}{ Mean } \\
\hline & 0 & 3 & 6 & & 0 & 3 & 6 & & 0 & 3 & 6 & & 0 & 3 & 6 & \\
\hline $\mathbf{T}_{0}$ & 15.03 & 15.09 & 15.17 & 15.10 & 3.46 & 3.42 & 3.38 & 3.42 & 0.50 & 0.53 & 0.55 & 0.53 & 24.0 & 15.0 & 13.2 & 17.5 \\
\hline $\mathrm{T}_{1}$ & 15.04 & 15.10 & 15.19 & 15.11 & 3.50 & 3.43 & 3.41 & 3.45 & 0.47 & 0.50 & 0.52 & 0.50 & 24.0 & 16.0 & 13.2 & 17.7 \\
\hline $\mathbf{T}_{2}$ & 15.02 & 15.10 & 15.20 & 15.11 & 3.52 & 3.46 & 3.42 & 3.47 & 0.46 & 0.49 & 0.51 & 0.49 & 24.2 & 17.2 & 13.4 & 18.3 \\
\hline $\mathrm{T}_{3}$ & 15.01 & 15.11 & 15.21 & 15.11 & 3.54 & 3.47 & 3.43 & 3.48 & 0.44 & 0.47 & 0.49 & 0.47 & 24.3 & 18.7 & 13.7 & 18.9 \\
\hline $\mathbf{T}_{4}$ & 15.02 & 15.12 & 15.21 & 15.12 & 3.54 & 3.48 & 3.44 & 3.49 & 0.42 & 0.45 & 0.48 & 0.45 & 24.3 & 19.2 & 14.1 & 19.2 \\
\hline $\mathrm{T}_{5}$ & 15.03 & 15.14 & 15.25 & 15.13 & 3.56 & 3.49 & 3.44 & 3.50 & 0.40 & 0.43 & 0.46 & 0.43 & 24.4 & 19.5 & 14.4 & 19.4 \\
\hline $\mathrm{T}_{6}$ & 15.03 & 15.14 & 15.23 & 15.13 & 3.56 & 3.50 & 3.46 & 3.51 & 0.41 & 0.43 & 0.46 & 0.44 & 24.4 & 19.6 & 14.4 & 19.4 \\
\hline C.D. at $5 \%$ & 0.069 & 0.083 & 0.345 & & 0.069 & 0.341 & 0.062 & & 0.032 & 0.007 & 0.070 & & 0.083 & 0.088 & 0.069 & \\
\hline S. Em. (士) & 0.159 & 0.191 & 0.794 & & 0.159 & 0.784 & 0.142 & & 0.073 & 0.016 & 0.162 & & 0.191 & 0.203 & 0.159 & \\
\hline
\end{tabular}

Table 3: Effect of treatments on physiochemical properties of Kinnow Aonla RTS (2010-2011).

\begin{tabular}{|c|c|c|c|c|c|c|c|c|c|c|c|c|c|c|c|c|}
\hline \multirow{3}{*}{ Treatment } & \multicolumn{4}{|c|}{ Colour/Appearance } & \multicolumn{4}{|c|}{ Texture/ Body } & \multicolumn{4}{|c|}{ Flavour/ Taste } & \multicolumn{4}{|c|}{ Overallacceptability } \\
\hline & \multicolumn{3}{|c|}{ Months after storage } & \multirow{2}{*}{ Mean } & \multicolumn{3}{|c|}{ Months after storage } & \multirow[t]{2}{*}{ Mean } & \multicolumn{3}{|c|}{ Months after storage } & \multirow{2}{*}{ Mean } & \multicolumn{3}{|c|}{ Months after storage } & \multirow{2}{*}{ Mean } \\
\hline & 0 & 3 & 6 & & 0 & 3 & 6 & & 0 & 3 & 6 & & 0 & 3 & 6 & \\
\hline $\mathrm{T}_{0}$ & 6.16 & 5.98 & 5.55 & 5.90 & 6.60 & 6.49 & 6.24 & 6.44 & 7.35 & 7.20 & 6.93 & 7.16 & 6.70 & 6.56 & 6.24 & 6.50 \\
\hline$T_{1}$ & 6.21 & 6.03 & 5.61 & 5.95 & 6.99 & 6.84 & 6.59 & 6.81 & 7.55 & 7.41 & 7.22 & 7.39 & 6.92 & 6.76 & 6.47 & 6.72 \\
\hline$T_{2}$ & 6.38 & 6.16 & 5.88 & 6.14 & 7.35 & 7.20 & 6.93 & 7.16 & 7.57 & 7.44 & 7.26 & 7.42 & 7.10 & 6.93 & 6.69 & 6.91 \\
\hline $\mathrm{T}_{3}$ & 6.87 & 6.73 & 6.44 & 6.68 & 7.22 & 7.10 & 6.88 & 7.07 & 7.70 & 7.58 & 7.40 & 7.56 & 7.26 & 7.14 & 6.91 & 7.10 \\
\hline$T_{4}$ & 6.60 & 6.55 & 6.25 & 6.47 & 7.74 & 7.59 & 7.32 & 7.55 & 8.00 & 7.86 & 7.66 & 7.84 & 7.45 & 7.33 & 7.08 & 7.29 \\
\hline$T_{5}$ & 7.23 & 7.15 & 6.97 & 7.12 & 8.09 & 7.94 & 7.67 & 7.90 & 8.48 & 8.35 & 8.16 & 8.33 & 7.93 & 7.81 & 7.60 & 7.78 \\
\hline$T_{6}$ & 7.04 & 6.89 & 6.62 & 6.85 & 7.92 & 7.77 & 7.50 & 7.73 & 8.25 & 8.13 & 7.95 & 8.11 & 7.74 & 7.60 & 7.36 & 7.57 \\
\hline C.D. at $5 \%$ & 0.077 & 0.095 & 0.080 & & 0.098 & 0.127 & 0.077 & & 0.095 & 0.092 & 0.089 & & 0.094 & 0.249 & 0.138 & \\
\hline S. Em. (士) & 0.178 & 0.218 & 0.185 & & 0.224 & 0.293 & 0.177 & & 0.218 & 0.211 & 0.204 & & 0.216 & 0.572 & 0.317 & \\
\hline
\end{tabular}

Table 4: Effect of treatments on organoleptic properties of Kinnow Aonla RTS (2010-2011).

Kinnow Aonla ready to serve is presented in Table 3. Data showed that treated sample differ from control for the parameter of acidity. Highest acidity $(0.53 \%)$ was recorded in $\mathrm{T}_{0}$ (Control) while lowest $(0.43 \%)$ was observed in $\mathrm{T}_{5}$ (ginger powder @100 gram/ lit). Highest acidity in aspartame treated sample was due to acidic nature of aspartame. There was gradual increase in acidity in all treatments during storage up to 180 days. This increase in acidity was attributed to the degradation of sugars into herbs [21].Increase in per cent acidity might be due to the slight growth of micro-organism in the beverage $[22,23]$.

\section{Ascorbic acid}

Marginal differences in ascorbic acid contents were observed in various treatments. Treated samples also differed from control samples with respect to ascorbic acid contents (Table 3). Statistical Analysis showed that the results are highly significant for storage period. Ascorbic acid contents decreased significantly at all storage intervals. These losses of ascorbic acid were attributed to the effect of processing, storage time and exposure to light. Highest ascorbic acid (19.4\%) was recorded in $\mathrm{T}_{6}$ (ginger powder @150 gram/ lit) and (19.4\%) followed by $\mathrm{T}_{5}$ (ginger powder @100 gram/ lit). While lowest (17.5\%) was observed in $\mathrm{T}_{0}$ (Control). The degradation of ascorbic acid in juice or RTS may follow aerobic and an-aerobic pathways. Similar decreasing trend for ascorbic acid contents in different fruit beverages were also reported by Gomez and Muhammad [24,25] in Kinnow juice blend.

\section{Colour/appearance}

The effect of treatments on Colour and Appearanceof Kinnow Aonla RTS is herbs depicted in Table 4. $\mathrm{T}_{5}$ (ginger powder @100 gram/ lit)was (7.97 score) ranked highest for Colour and Appearancescore this (6.68 score), (6.62 score) and (6.47 score) was followed by
$\mathrm{T}_{3}$ (Cardamom powder @150 gram/ lit), $\mathrm{T}_{6}$ (ginger powder @150 gram) and $\mathrm{T}_{4}$ (ginger powder @50 gram/ lit). $\mathrm{T}_{0}$ (Control) was (5.90 score) ranked lowest as regard to its Colour/Appearance characteristics. Storage had a significant effect on colour perception of diet drink. The maximum scores for Colour and Appearance were observed when it was freshly prepared in $\mathrm{T}_{5}$ (ginger powder @100 gram/ lit). As the storage period increased, a slight decline in Colour and Appearance score. Previous studies by Bezman [26] also reported similar loss in colour during storage of beverage samples.

\section{Texture/ body}

Texture and body of the diet drink was affected significantly by treatments. $\mathrm{T}_{5}$ (ginger powder @100 gram/ lit)got (7.90 score) the maximum score for texture and body was followed by (7.73 score) $\mathrm{T}_{6}$ (ginger powder @150 gram/ lit), (7.55 score) $\mathrm{T}_{4}$ (ginger powder @50 gram/ lit) and (7.16 score) in $\mathrm{T}_{2}$ (Cardamom powder @100 gram/ lit). The lower texture and body perception (6.44 score) was recorded in $\mathrm{T}_{0}$ (Control). A significant variation was observed in flavor perception of diet beverage at various storage levels. The maximum scores for texture and body (8.09 score) were observed $\mathrm{T}_{5}$ (ginger powder @100 $\mathrm{gram} / \mathrm{lit}$ )when it was freshly prepared. As the storage period increased, a slight decline in texture and body score was experienced (Table 4). The gradual loss in texture and body scores over the entire storage period was due to changes in volatile compounds of the drink. Texture and body deterioration in beverage products was also reported by Bezman and Jain [26,27].

\section{Flavour/ taste}

In organoleptic evaluation flavor and taste is very important factor after colour and texture. Statistical Analysis revealed a significant effect 
Citation: Balaji V, Prasad VM (2014) Studies on Value Added Kinnow - Aonla Blended Ready to Serve Beverage. J Food Process Technol 5: 288. doi:10.4172/2157-7110.1000288

of treatment and storage on flavor and taste Kinnow Aonla RTS. $\mathrm{T}_{5}$ (ginger powder @100 gram/ lit) sample (8.33 score) got higher scores of flavor and taste was followed by (8.11 score) $\mathrm{T}_{6}$ (ginger powder @150 gram/ lit), (7.84 score) $\mathrm{T}_{4}$ (ginger powder @50 gram/ lit) and (7.56 score) in $\mathrm{T}_{3}$ (Cardamom powder @150 gram/ lit) then (7.42score) $\mathrm{T}_{2}$ (Cardamom powder @100 gram/ lit) as compared to treated samples (Table 4). It was noted that Kinnow Aonla produces without herbs got less scores as compared to RTS samples in which combination of herbals were used. A significant variation was observed in flavor and taste of RTS at various storage levels. The maximum scores for flavor and taste (8.48 score) was observed $\mathrm{T}_{5}$ (ginger powder @100 gram/ lit) when it was freshly prepared. As the storage period increased, a slight decline in flavor and taste score was experienced (Table 4). The gradual loss in flavor and taste scores over the entire storage period was due to changes in volatile compounds of the Kinnow Aonla Beverages [28]. The flavor and taste difference and loss might be due to time and temperature and duration of storage. Similar findings were also reported by Jain [27].

\section{Overall acceptability}

Overall acceptability was influenced significantly with the treatment. Higher level of herbal could not produce top acceptability due to deviation from standard Colour, Texture, Flavor of the product retained after $6^{\text {th }}$ month of storage. Though, the best result was recorded (7.78 score) in $\mathrm{T}_{5}$ (ginger powder @100 gram/ lit). Closely followed by (7.57 score) in $\mathrm{T}_{6}$ (ginger powder @150 gram/ lit). Even control was not better as compared to different level of herbs. No certain pattern was observed with overall acceptability with treatment concerned. Storage duration had influence on overall acceptability which was initially 7.16 score and reduced 6.14 score after $6^{\text {th }}$ months of storage

\section{Conclusion}

It can be concluded from this study that, the Herbals can be effectively used as alternative source of value addition in Kinnow Aonla RTS. On the basis of results obtained it may be concluded that treatment $\mathrm{T}_{5}$ (ginger powder @100 gram/ lit) can be used in commercialization of Kinnow-Aonla RTS. All of the sensory parameters decline slightly during storage but remain in acceptable region even after 180 days of storage.

\section{References}

1. Singh V, Singh HK, Singh IS (2004) Evaluation of aonla varieties (EmblicaofficinalisGaertn.) for fruit processing. Haryana J HortSci 33: 18-19.

2. Barthakur NN, Arnold (1991) Chemical analysis of aonla (EmblicaofficinalisGreatn) and its potential as a food source. SciHort 47(1-2, 99-105).

3. Dachiya SP, DhawanSS(2001)Physico-Chemical characteristics of Aonla (EmblicaofficinalisGaertn) Chakaiya, IndFd Pack 55: 133.

4. Singh IS, Pathak RK Diwedi R, Singh HK (1996) Aonla production and postharvest technology, Buiietin, Dept of Horticulture, N.D. University, University of Agriculture and Technology, Faizabad.

5. Bezman Y, Russell L, Rouseff, Naim M (2001) 2-Methyl-3-furanthiol and methional are possible off-flavors in stored orange juice. J Agric Food Chem 49: $5425-5432$
6. Gorinstein S, Leontowicz $\mathrm{H}$, Leontowicz M, Krzeminski $\mathrm{R}$, Gralak $\mathrm{M}$, et al. (2004) Fresh Israeli Jaffa Blond (Shamouti) Orange and Israeli Jaffa Red Star Ruby (Sunrise) Grapefruit Juices affect plasma lipid metabolism and antioxidant capacity in rats fed with added cholesterol. J Agric Food Chem 52: 4853-4859.

7. Afshari, Ali Taghizadeh (2007) "The effect of ginger on diabetic nephropathy, plasma antioxidant capacity and lipid peroxidation in rats". Food Chemistry.

8. University of Maryland Medical Centre (2006) "Ginger".

9. Álvarez $L$ (2008) Cardamom prices leads to a re-emergence of the green gold

10. Anand JC (1970) Retention of added vitamin C in amla preserves. IndFd Pack 24: $19-20$.

11. Bakhru HK (1998) Garlic and ginger. Herbs that heal (Natural Remedies for good health ) art I: 91-99.

12. Singh IS, Kumar S (1995) Studies on processing of aonla fruits: II Aonla Products. ProgsHort 27: 39-47.

13. Rangana S (1991) Handbook of Analysis and Quality control for Fruits and Vegetables Products. Tata Mc-Graw Hill Publishing Company Limited, New Delhi, India.

14. Larmond E (1987) Laboratory methods for sensory evaluation of Foods, Deptt of Agri Canada Pub. No. 1637/E.

15. Steel RGD, Torrie JH, Dickey D (1997) Principles and Procedures of Statistics A Biometrical Approach. (3 ${ }^{\text {rd }}$ Edition). McGraw Hill Book Co, New York, USA.

16. Sarolia DK, Mukherjee S (2002) Comparative efficiency of different preservation methods in keeping quality of lime (Citrus aurantifolia) swingle juice during storage. Haryana J HortSci 31: 185-188.

17. Cardoso JMP, Bolini HMA (2007) Different sweeteners in peach nectar: Idea and equivalent sweetness. Food Res Int 40: 1249-1253.

18. Kaunjoso BWT, Luh BS (1967) Texture, Pectin and syrup viscosity of canned cling peaches. Food Technol 21: 139-142.

19. Saleem M (1980) Studies on the preparation of comminuted citrus fruit beverage base. M.Sc. thesis, Univ Agri Faisalabad.

20. Nath A, Yadav DS, Sarma P, Dev B (2005) Standardization of ginger-kinnow squash and its storage. Journal of Food Science and Technology 42: 520-522.

21. Bhardwaj RL, Mukherjee S (2011) Effects of fruit juice blending ratios on kinnow juice preservation at ambient storage condition. Afr J Food Sci 5: 281-286.

22. Rangana S (1991) Handbook of Analysis and Quality control for Fruits and Vegetables Products. Tata Mc-Graw Hill Publishing Company Limited, New Delhi, India.

23. Ranote PS, Bains GS (1982) Juice of Kinnow fruits. Indian Food Packer 36: 23-33.

24. Gomez, Saji, Khurdiya DS (2005) Quality changes in aonla pulp under different storage conditions. IndFd Pack 59: 54-57.

25. Muhammad R, Ahmed M, Chaudhry MA, Hussain B, Khan I (1987) Ascorbic acid quality retention in orange squashes as related to exposure to light and container type. Pak J Scilnd Res 30: 480-483.

26. Bezman Y, Russell L, Rouseff, Naim M (2001) 2-Methyl-3-furanthiol and methional are possible off-flavors in stored orange juice. J Agric Food Chem 49: $5425-5432$.

27. Jain S, Sankhla APK, Dashora A, Sankhla AK(2003) Physiochemical and sensory properties of orange drink. J Food Sci Tech India 40: 656-659.

28. Marcy JE, Graumlich TR, Grandall PG, Marshall MR (1984) Factors affecting storage of orange concentrate. J Food Sci 49: 1628-1629. 